\title{
Measurements of ambient HONO concentrations and vertical HONO flux above a northern Michigan forest canopy
}

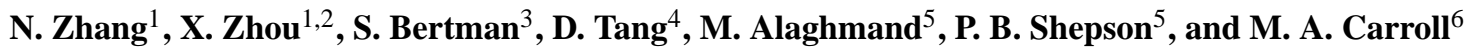 \\ ${ }^{1}$ Department of Environmental Health Sciences, State University of New York, Albany, NY 12201, USA \\ ${ }^{2}$ Wadsworth Center, New York State Department of Health, Albany, NY 12201, USA \\ ${ }^{3}$ Department of Chemistry, Western Michigan University, Kalamazoo, MI 49008, USA \\ ${ }^{4}$ Department of Psychology, Texas A\&M University, College Station, TX 77843, USA \\ ${ }^{5}$ Departments of Chemistry, Purdue University, West Lafayette, IN 47907, USA \\ ${ }^{6}$ Department of Atmospheric, Oceanic and Space Science, University of Michigan, Ann Arbor, MI 48109, USA
}

Correspondence to: X. Zhou (zhoux@wadsworth.org)

Received: 22 December 2011 - Published in Atmos. Chem. Phys. Discuss.: 13 March 2012

Revised: 25 July 2012 - Accepted: 23 August 2012 - Published: 13 September 2012

\begin{abstract}
Systems have been developed and deployed at a North Michigan forested site to measure ambient HONO and vertical HONO flux. The modified HONO measurement technique is based on aqueous scrubbing of HONO using a coil sampler, followed by azo dye derivatization and detection using a long-path absorption photometer (LPAP). A $\mathrm{Na}_{2} \mathrm{CO}_{3}$-coated denuder is used to generate "zero HONO" air for background correction. The lower detection limit of the method, defined by 3 times of the standard deviation of the signal, is $1 \mathrm{pptv}$ for 1-min averages, with an overall uncertainty of $\pm(1+0.05$ [HONO] $)$ pptv. The HONO flux measurement technique has been developed based on the relaxed eddy accumulation approach, deploying a 3D sonic anemometer and two HONO measurement systems. The overall uncertainty is estimated to be within $\pm\left(8 \times 10^{-8}+0.15 F_{\mathrm{HONO}}\right) \mathrm{mol} \mathrm{m}^{-2} \mathrm{~h}^{-1}$, with a 20 -min averaged data point per $30 \mathrm{~min}$. Ambient $\mathrm{HONO}$ and vertical HONO flux were measured simultaneously at the PROPHET site from 17 July to 7 August 2008. The forest canopy was found to be a net HONO source, with a mean upward flux of $0.37 \times 10^{-6}$ moles $\mathrm{m}^{-2} \mathrm{~h}^{-1}$. The HONO flux reached a maximal mean of $\sim 0.7 \times 10^{-6}$ moles $\mathrm{m}^{-2} \mathrm{~h}^{-1}$ around solar noon, contributing a major fraction to the HONO source strength required to sustain the observed ambient concentration of $\sim 70 \mathrm{pptv}$. There were no significant correlations between $\left[\mathrm{NO}_{\mathrm{x}}\right]$ and daytime $\mathrm{HONO}$ flux and between $J_{\mathrm{NO}_{2}} \times\left[\mathrm{NO}_{2}\right]$ and $\mathrm{HONO}$ flux, suggesting that $\mathrm{NO}_{\mathrm{x}}$ was not an important precursor responsible for HONO daytime pro-
\end{abstract}

duction on the forest canopy surface in this low- $\mathrm{NO}_{\mathrm{x}}$ rural environment. Evidence supports the hypothesis that photolysis of $\mathrm{HNO}_{3}$ deposited on the forest canopy surface is a major daytime HONO source.

\section{Introduction}

Nitrous acid (HONO) is a trace gas in the atmosphere, but it is an important component of $\mathrm{NO}_{\mathrm{y}}$. Photolysis of HONO produces hydroxyl radical $(\mathrm{OH})$, the primary oxidant in the atmosphere responsible for the degradation of most of air pollutants and toxics. It is estimated that HONO photolysis accounts for up to $80 \%$ of $\mathrm{OH}$ production during early morning hours (Elshorbany et al., 2009; Ren et al., 2006; Vogel et al., 2003) and contributes to $20-60 \%$ of the daily $\mathrm{OH}$ production (Acker et al., 2006; Alicke et al., 2002, 2003; Kleffmann et al., 2005; Villena et al., 2011; Zhou et al., 2002a, 2007). In addition, HONO is in an intermediate oxidation state and can be produced from nitrogen-containing precursors with higher oxidation states such as $\mathrm{NO}_{2}$ and $\mathrm{HNO}_{3}$, or lower oxidation states such as NO. HONO chemistry is essential in understanding the cycling of reactive nitrogen compounds in the troposphere.

Many studies indicated that most HONO observed in the atmospheric boundary layer is produced by heterogeneous reactions on ground surfaces (including soil, buildings and vegetation) (Acker et al., 2004; Bröske et al., 2003; Grassian,

Published by Copernicus Publications on behalf of the European Geosciences Union. 
2002; He et al., 2006; Kleffmann et al., 2003; Kleffmann and Wiesen, 2005; Ndour et al., 2008; Veitel et al., 2002; Zhang et al., 2009; Zhou et al., 2002a). To assess quantitatively the source strength on HONO on ground surface, measurement of exchange flux of HONO between the ground and the atmosphere is essential. However, there are only a few HONO flux measurements reported in literature (Beine et al., 2005, 2006; Harrison and Kitto, 1994; Honrath et al., 2002; Ren et al., 2011; Stutz et al., 2002; Zhou et al., 2001, 2011); most of these HONO flux measurements were made based on an indirect gradient method, which is less accurate due to the large scatter of the concentration measurements and the influence of chemical transformation during the turbulent transport process (Galmarini et al., 1997).

In the effort described here, a system was developed for direct measurement of HONO flux, based on a relaxed eddy accumulation technique (REA). The REA technique allows flux measurement with sensors that have much slower response time, such as gas chromatography and mass spectrometry (Bowling et al., 1998) and has been successfully used to measure a number of chemical species, such as $\mathrm{CO}_{2}, \mathrm{H}_{2} \mathrm{O}, \mathrm{N}_{2} \mathrm{O}$ and biogenic VOCs. Comparison studies have shown excellent agreement between fluxes of reactive compounds determined by Eddy covariance (EC) and REA techniques (Bowling et al., 1998; Pattey et al., 1993; Westberg et al., 2001). Here we report measurements of HONO flux, along with HONO ambient concentrations over a forest canopy, using REA coupled with two modified HONO measurement systems based on coil sampling, azo dye derivatization and long-path absorption photometric (LPAP) detection (Huang et al., 2002; He et al., 2006). The results quantitatively reveal the role of canopy surfaces on HONO heterogeneous formation.

\section{Experimental}

\subsection{Site description}

HONO concentration and flux were simultaneously measured on a $31-\mathrm{m}$ scaffolding tower at the PROPHET site at the University of Michigan Biological Station $\left(45^{\circ} 30^{\prime} \mathrm{N}\right.$, $84^{\circ} 42^{\prime} \mathrm{W}$, elevation $238 \mathrm{~m}$ ) from 17 July to 7 August 2008. The PROPHET site is located in an undisturbed and wellcharacterized, mixed deciduous/coniferous forest with the major tree species of aspen, maple, red oak, pine and beech. Average canopy height is $\sim 21 \mathrm{~m}$. Air masses reaching this site are dominated by westerly flow: southwesterly flow is generally polluted air from metropolitan and industrial areas (e.g. Chicago and Milwaukee) and northwesterly flow is relatively clean air from Canada (Cooper et al., 2001). A complete description of the site has been given in (Carroll et al., 2001).

\subsection{HONO concentration measurement}

Three LPAP systems (Fig. 1), a modification based on the method of Huang et al. (2002) and He et al. (2006), were used in this study: one for ambient HONO concentration measurement and two for HONO flux measurement (described below). Briefly, ambient HONO was scrubbed by de-ionized (DI) water (resistance $>18.2 \mathrm{M} \Omega \mathrm{cm}$ ) using a coil sampler; the scrubbed nitrite was derivatized with $2 \mathrm{mM}$ sulfanilamide (SA) and 0.2 mM n-(1-naphthyl)-ethylenediamine (NED) in a 1-ml thermostatic derivatization coil at $50{ }^{\circ} \mathrm{C}$. The azo dye derivative was quantified by light absorbance at $540 \mathrm{~nm}$ using a miniature fiber optic spectrometer (USB2000, Ocean Optics) with a 1-m liquid-waveguide capillary flow cell (WPI). The system was operating on a 30-min cycle controlled by an all-PTFE 3-way miniature solenoid valve (series 1, Parker): sampling ambient air for $20 \mathrm{~min}$ (measurement mode) and then "zero-HONO" air for $10 \mathrm{~min}$ to obtain a baseline (zero mode). The zero air was generated by pulling ambient air through a $\mathrm{NaCO}_{3}$ coated annular denuder (URG-2000-30x150-3CSS, URG). Gaseous acidic species, including HONO, are quantitatively removed by the denuder (at a collection efficiency of $\geq 99 \%$ at a flow rate of $\leq 101 \mathrm{~min}^{-1}$, http://www.urgcorp.com/library/ datasheets/), but aerosols and most other gases, including potential interferences such as $\mathrm{NO}_{\mathrm{x}}$, are allowed to pass through (USEPA, 1999). The absorbance signal collection frequency was $0.3 \mathrm{~Hz}$.

\subsection{REA flux system}

The HONO flux system was developed based on the relaxed eddy accumulation (REA) technique which involves conditional sampling of air into updraft and downdraft components at a constant flow rate (Bowling et al., 1998). The duration of sampling for each component is only related to the frequency at which the wind eddy changes in vertical direction. Air samples collected in each component were accumulated over a collection period before determination of concentrations. The Flux $(F)$ is calculated using the following relationship (Businger and Oncley, 1990):

$F=\beta \sigma_{w}\left(\bar{C}_{\mathrm{up}}-\bar{C}_{\mathrm{dn}}\right)$

where $\beta$ is an empirically determined coefficient with a value of $\sim 0.6$ over a smooth surface (Businger and Oncley, 1990; Westberg et al., 2001), $\sigma_{w}$ is the standard deviation of vertical wind sector over the collection period, and $\bar{C}_{\text {up }}$ and $\bar{C}_{\mathrm{dn}}$ are the average concentrations of HONO in the updraft and downdraft components, respectively.

The HONO flux measurement system is illustrated in Fig. 2, consisting of a three-dimensional sonic anemometer and two LPAP systems. A CSAT3 3-D sonic anemometer (Campbell Scientific) was mounted at $\sim 11 \mathrm{~m}$ above the canopy level on an arm extending $\sim 1.5 \mathrm{~m}$ away from the west side of the tower facing the prevailing wind and used 


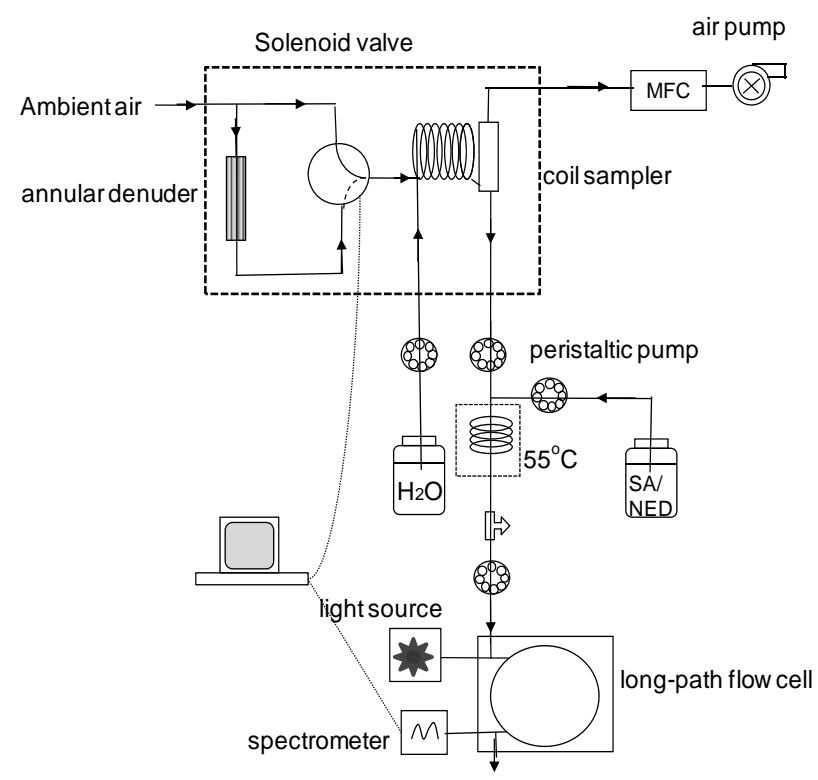

Fig. 1. A schematic diagram of a HONO measurement system.

to acquire wind speed at $10 \mathrm{~Hz}$. During flux measurement, the value of $\sigma_{w}$ was determined by the vertical wind from the previous 30-min period. A dynamic threshold (deadband) $w_{T}=\sigma_{w} / 2$ was used to increase the concentration difference between the reservoirs (Bowling et al., 1998; Pattey et al., 1993). The vertical component of the instantaneous wind velocity, $w$, was compared to a threshold $w_{T}$. Based on this comparison, a laptop computer was used to control the switching of two 3-way valves for conditional sampling (Table 1): for $w>w_{T}$, ambient air was collected into an updraft component and zero air flows through a downdraft component; for $w<-w_{T}$, ambient air was sampled into a downdraft component and zero air flows through an updraft component; for $-w_{T}<w<w_{T}$, zero air flew into both components.

Two HONO measurement systems described above were used to measure HONO concentrations in the up and down air drafts. The systems were operated over the same 30-min cycle as the ambient measurement system. During the 20min measurement mode, both up and down systems were doing conditioned sampling (Table 1). Sample flow rate in each of the three channels (Up + Down + Ambient) was maintained at a constant rate of $21 \mathrm{~min}^{-1}$. Ambient air was pulled into scrubbing samplers through a 2.2-m PFA tube (3.2-mm ID) inlet extended near the anemometer probe at a total flow rate of $61 \mathrm{~min}^{-1}$. A LabVIEW program was developed for the communication with the sonic anemometer and REA valves.

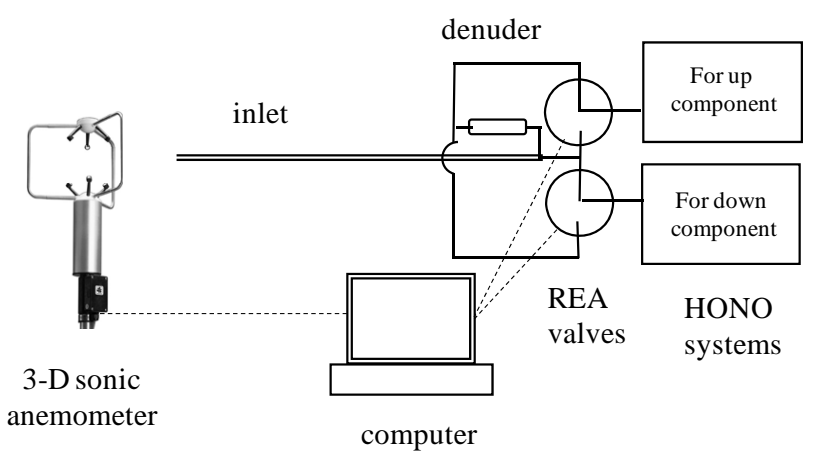

Fig. 2. A schematic diagram of a REA HONO flux measurement setup, consisting of a 3-D sonic anemometer to measure vertical wind, a $\mathrm{Na}_{2} \mathrm{CO}_{3}$-coated annular denuder to generate "zero-HONO" air, and two LPAP systems to measure HONO concentrations in the up- and down-draft air. A computer acquires and processes 3-D wind data, and controls the REA valves based on the vertical wind information.

Table 1. Sampling status in the three HONO measurement systems in a 30-min cycle.

\begin{tabular}{|c|c|c|}
\hline System & "Measurement" (20 min) & "Zero" (10 min) \\
\hline Updraft & $\begin{array}{l}\text { ambient air when } w>w_{T} \text {, } \\
\text { otherwise zero air }\end{array}$ & zero air \\
\hline Downdraft & $\begin{array}{l}\text { ambient air when } w<-w_{T} \text {, } \\
\text { otherwise zero air }\end{array}$ & zero air \\
\hline Ambient & ambient air & zero air \\
\hline
\end{tabular}

\subsection{Calibration}

Calibration was performed by introducing aqueous $\mathrm{NaNO}_{2}$ standard solutions in place of scrubbing solution into the HONO measurement system in the zero mode. The signal height was plotted against the nitrite concentration to yield a calibration curve for the ambient concentration channel. For HONO flux measurement, the signal area above the baseline was integrated to calculate the amount of nitrite collected during the sampling period, based on the $\mathrm{NaNO}_{2}$ calibration curve and the solution delivery flow rate. Three full range, multipoint calibrations were conducted at the beginning, middle, and end of the campaign. A single point calibration was made for every batch of reagent solutions, which usually lasted for 2 days. Correlation coefficients $r^{2}$ were $\geq 0.999$ for both sets of calibration curves.

\subsection{HONO photolysis rate constant}

The total solar ultraviolet intensity $(295-385 \mathrm{~nm})$ was measured using an Eppley TUVR radiometer (UVmeasured) with a detection limit of $0.3 \mathrm{~W} \mathrm{~m}^{-2}$ and overall uncertainty of $10 \%$ (Carroll et al., 2001). The radiative transfer model (http://cprm.acd.ucar.edu/Models/TUV/ 
Interactive_TUV/) was used to calculate HONO photolysis rate constant $\left(J_{\text {HONO }}^{\text {model }}\right)$ and total UV intensity between $295 \mathrm{~nm}$ and $385 \mathrm{~nm}$ (UV ${ }^{\text {model }}$ ) for clear sky conditions, taking into account the climatological $\mathrm{O}_{3}$ column and aerosol optical depth, time of day and month, and location of the sampling site. Correction was made for variable cloud cover using the following equation (Kleinman et al., 1995):

$$
\begin{aligned}
& J_{\mathrm{HONO}}=J_{\mathrm{HONO}}^{\text {model }} \times\left(\mathrm{UV}^{\text {measured }} /\right. \\
& \left.\mathrm{UV}{ }^{\text {model }}\right) /\left(\mathrm{UV}^{\text {measured* }} / \mathrm{UV}^{\text {model } *}\right)
\end{aligned}
$$

where the $\mathrm{UV}^{\text {measured* }}$ and $\mathrm{UV}^{\text {model* }}$ are the modeled and measured UV intensities at solar noon under clear sky.

\section{$2.6 \mathrm{NO}_{\mathrm{x}}$ measurements}

$\mathrm{NO}_{\mathrm{x}}$ : $\mathrm{NO}$ and $\mathrm{NO}_{2}$ were measured with a custom-built analyzer using the chemiluminescence technique constructed as described by Ridley and Grahek (1990) and Alaghmand et al. (2011). The chemiluminescence photons were detected using a Burle Industries 8852 photomultiplier tube, cooled with dry ice, and a Hamamatsu photon counting system. The instrument incorporates a blue light LED $\mathrm{NO}_{2}$ photolytic converter. The average $\mathrm{NO}_{2}$ conversion efficiency for a flow rate of $1.2 \mathrm{slpm}$ was determined to be $28.6 \pm 0.9 \%$. For 5 - $\mathrm{min}$ averaged data, the detection limit was 7 pptv for both $\mathrm{NO}$ and $\mathrm{NO}_{2}$.

\subsection{Meteorological parameters}

Temperature, dew point, precipitation, relative humidity and weather conditions were acquired through the website (http:// www.wunderground.com) for Pellston Airport, about $5.5 \mathrm{~km}$ from the PROPHET site. Back trajectories at both $50 \mathrm{~m}$ and $500 \mathrm{~m}$ above the ground levels were calculated using HYSPLIT (HYbrid Single-Particle Lagrangian Integrated Trajectory) Model (Draxler and Rolph, 2003) to identify the air source region.

\section{Results and discussion}

\subsection{Ambient HONO system performance}

Two major modifications were made to the original method of Huang et al. (2002), including: (1) HPLC/UV-vis detection technique was replaced by the LPAP technique using a miniature fiber optic spectrometer with a 1-m flow cell, and (2) a 3-way solenoid valve was used to alternately introduce ambient air or "zero-HONO" air to a coil sampler. The sensitivity of the LPAP technique is greatly enhanced compared to the conventional spectrophotometric method, by two orders of magnitude (He et al., 2006). It eliminates the use of organic solvents as a mobile phase in the HPLC method, which is a significant advantage since organic solvent usage in the field may interfere with measurements of organic species. The light absorbance signal was collected at a rate of $0.3 \mathrm{~Hz}$, with an alternated sampling cycle of ambient air and "zero-HONO" air. While the $\mathrm{Na}_{2} \mathrm{CO}_{3}$ coated denuder removed HONO and acidic gases from the ambient air (> $99 \%$ ), it allowed most of the potential interfering species such as $\mathrm{NO}, \mathrm{NO}_{2}, \mathrm{PAN}$, nitrate and aerosol, to pass (USEPA, 1999). Therefore, interference from these species was mostly eliminated by subtracting the "zero-HONO" signals from the ambient air signals.

Figure 3 shows an excerpt of 10-min raw data recorded in the morning of 25 July 2008 . The $90 \%$ response time, based on the signal transition from "zero-HONO" air to ambient air, was about $110 \mathrm{~s}$. The response time may be further shortened by increasing the rates of scrubbing and reagent flows and by reducing the length of tubing in the liquid flow plumbing. The ambient concentrations were derived from the difference between the ambient signals and the "zero-HONO" air. The "zero-HONO" baseline drifted only slowly throughout the day in response to factors including concentrations of interfering species (e.g. $\mathrm{NO}_{\mathrm{x}}$ ), temperature and reagent age. The baseline drift was within 20 pptv day ${ }^{-1}$, with a minimum a few hours after midnight and a maximum in the mid afternoon. After removing the transitional data points, 17-18 min of ambient HONO concentration data were collected in each 30-min cycle (Fig. 4, lower panels). The raw data were reduced into 1-min averages.

The lower detection limit of the method is estimated to be $\sim 1$ pptv, based on 3 times the standard deviation of the zero air signal. The linear dynamic range is $1-5000$ pptv; above $5000 \mathrm{pptv}$, the signal becomes non-linear. The upper limit of linear dynamic range can be improved by increasing the rates of scrubbing and reagent flows and by reducing the air sampling flow rate. These measures, however, will increase the lower detection limit. The measurement precision, based on side-by-side measurements using multiple LPAP systems, is estimated to be better than $2 \%$ in the concentration range of $50 \mathrm{pptv}$ to $5 \mathrm{ppbv}$. An overall uncertainty of $\pm(1+0.05$ [HONO]) pptv is estimated, accounting for uncertainties in signal acquisition and processing, air and liquid flow rates, and standard preparation.

\subsection{HONO flux system characterization}

\subsubsection{Coordinate transformation}

As most surfaces are not perfectly flat, the vertical wind fluctuations are often affected by the mean horizontal wind (Chahuneau et al., 1989). During the 2 weeks prior to the measurement of HONO flux at the site, 3-D wind data were collected by the anemometer. The collected wind data were used for coordinate transformation (Wilczak et al., 2001), to align wind data collected during flux measurement with the 


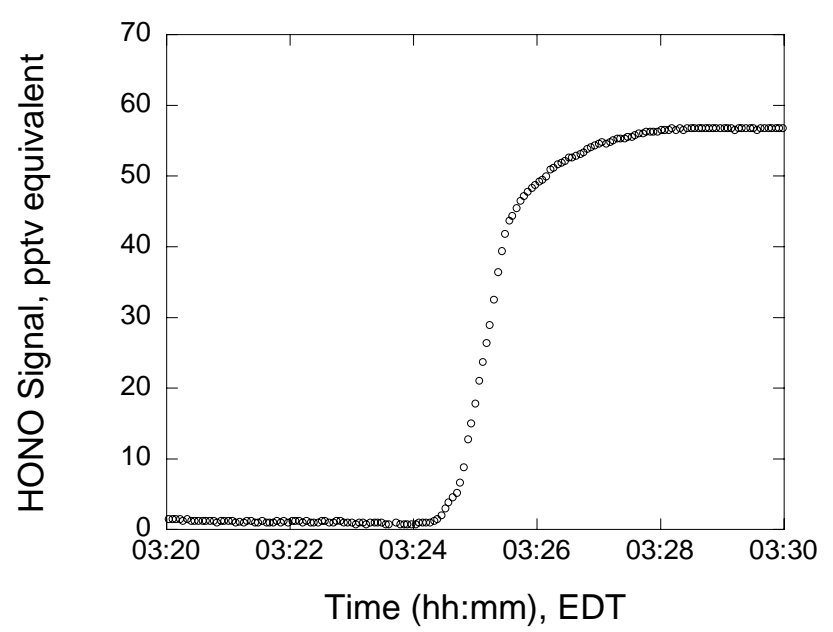

Fig. 3. An excerpt of 10-min HONO raw data during the transition from the "zero-HONO" baseline to ambient HONO measurement, 25 July 2008. The time in the x-axis is Eastern Daytime-saving Time (EDT, GMT - 04:00).

mean wind streamlines, and thus when $w=0$, the average flux of dry air perpendicular to the surfaces of interest is zero.

\subsubsection{Proportionality coefficient, $\beta$}

The value of $\beta$ in Eq. (1) is about 0.6 over a smooth and flat surface with a dynamic threshold (deadband) set at zero. However, in REA application for flux measurements, a nonzero deadband is commonly used to improve the sensitivity of the measurement and prolong the life of the REA valves, which also results in decreases in the effective sampling time (Oncley et al., 1993) and the $\beta$ value (Pattey et al., 1993). The $\beta$ value is generally constant when a dynamic deadband $w_{T}=\sigma_{w} / 2$ is used, and is computed in two ways: by conditionally sampling the vertical wind velocity $(w)$ and sonic temperature ( $T$ ) (Businger and Oncley, 1990; Westberg et al., 2001). We lose the air temperature data due to some technical problems with our software, thus we computed the $\beta$ coefficient using the vertical wind measurement:

$\beta=\frac{\overline{w^{\prime} w^{\prime}}}{\sigma_{w} \Delta w}$

where $w^{\prime}$ is the fluctuating components of the instantaneous measured vertical wind velocity $(w), \sigma_{w}$ is the standard deviation of $w$, and $\Delta w$ the difference in the conditionally sampled $w$. A $\beta$ value of $0.442 \pm 0.016$ was derived from 3 -h vertical wind data around noontime on 15 July 2008, and was used for the HONO flux calculation. The derived $\beta$ value is in good agreement with the value of 0.43 calculated based on the formula suggested by Businger and Oncley (1990):

$\beta=\beta_{\mathrm{o}} \exp \left(-0.75 \frac{w_{T}}{\sigma_{w}}\right)$

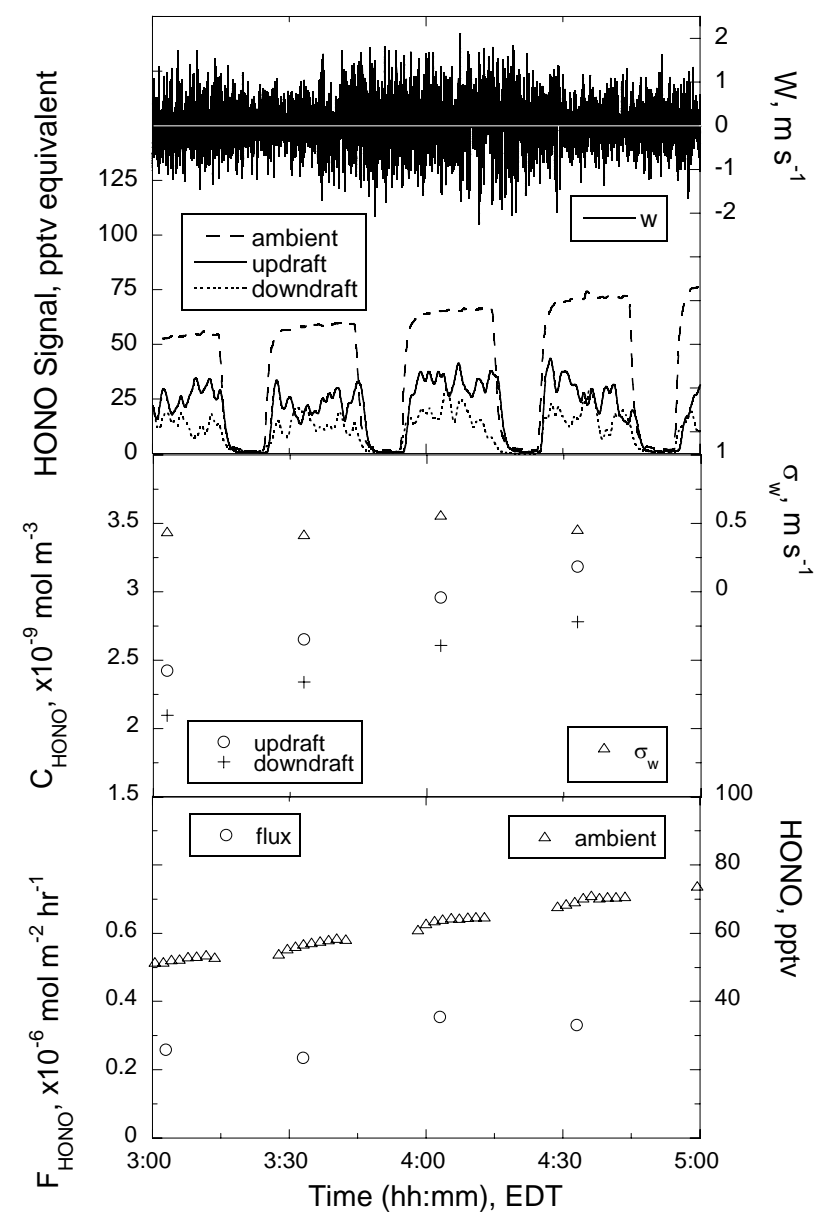

Fig. 4. Examples of raw and processed data collected during a 2h period on 25 July 2008. Upper panel: raw data of vertical wind speed $(10 \mathrm{~Hz})$ and $\mathrm{HONO}$ signals $(0.3 \mathrm{~Hz})$ from ambient, updraft and downdraft HONO systems. Middle panel: 20-min averages of HONO concentrations in updraft and downdraft air masses, and the standard deviation of vertical wind speed. Lower panel: derived ambient HONO concentrations and flux values.

with $\beta_{\mathrm{o}}$ value of 0.627 and a $w_{T}$ of $\sigma_{w} / 2$ (Businger and Oncley, 1990; Westberg et al., 2001). It is also in good agreement with the reported values of $0.471 \pm 0.007$ based on vertical wind velocity and $0.438 \pm 0.017$ based on sonic temperature at the PROPHET site (Westberg et al., 2001), and $0.410 \pm 0.018$ at Bakersfield site and $0.441 \pm 0.008$ at Blodgett Forest site in California (Ren et al., 2011).

\subsubsection{Sampling inlet, time lag, and flow dynamics}

A PFA sampling line (2.2 m, 3.2-mm ID) was used to pull ambient air near the anemometer probe at a total flow rate of $61 \mathrm{~min}^{-1}$, resulting in a lag time of $206 \mathrm{~ms}$ for air to flow through a total volume of $20.6 \mathrm{ml}$ in a down facing Teflon elbow, a 220-cm 0.32-cm ID Teflon common inlet tubing, and Teflon cross fitting splitting the flow. A delay time of $200 \mathrm{~ms}$ 
was set to trigger the sampling valve, without taking into consideration the time lag of $\sim 100 \mathrm{~ms}$ due to data acquisition at $10 \mathrm{~Hz}$. As a result, there was a time offset of about $100 \mathrm{~ms}$ in the actual sampling of the up or down component; the REA system might miss the high frequency signals and result in underestimations in the concentration difference and the calculated flux. However, the error should be relatively minor, since $70 \%$ of the conditioned sampling occurred with duration of $>1 \mathrm{~s}$, and the median was $2.7 \mathrm{~s}$, much longer than the $100 \mathrm{~ms}$ offset.

The Reynolds number is calculated to be about 2700 for an air flow of $61 \mathrm{~min}^{-1}$ through a 3.2-mm ID sampling inlet, and thus the flow in the inlet line was in the transitional regime, which may result in some frequency attenuation (Ammann et al., 2006). However, our inlet (2.2 $\mathrm{m}$ ) was much shorter than that $(30 \mathrm{~m})$ by Ammann et al. (2006), resulting in a much shorter air residence time $(\sim 200 \mathrm{~ms}$ vs. $4.3 \mathrm{~s})$. The attenuation in turbulent fluctuation may be a small fraction of the air residence time in the inlet tube and would be much shorter than the median duration time of $2.7 \mathrm{~s}$ for a turbulent air parcels. Therefore, the fluctuation of signals should not be affected to any significant degree by the flow conditions in the inlet tube.

HONO may be artificially formed on the inlet tubing wall, especially when sampling high $\mathrm{NO}_{\mathrm{x}}$ urban air. We have previously examined this sampling interference several times at this and other low- $\mathrm{NO}_{\mathrm{x}}$ sites (Zhou et al., 2001, 2002b; He et al., 2006). We found that the exposure of Pyrex and PFA inlets to sunlight led to significant artificial HONO signals. No significant interference was observed when the inlet was protected from the sunlight, as demonstrated by the excellent agreement (i.e. within analytical uncertainty of 2-3\%) between the signals of two channels, one without any extra inlet and the other with a long inlet (up to $30 \mathrm{~m}$ ). In this study, the inlet tubing was shielded from sunlight with aluminum foil. It was $2.2 \mathrm{~m}$ and the residence time was $\sim 200 \mathrm{~ms}$, both relatively short; the inlet artifact on HONO measurement should be negligible. Even if the inlet artifact existed, the effect on HONO flux measurements would likely be cancelled out by taking the concentration difference.

\subsection{Data processing}

An example of raw data for vertical wind velocity by the anemometer and HONO signals recorded by the LPAP spectrometers are shown in the upper panels in Fig. 4. It is apparent that the vertical wind fluctuated around zero, with the length of individual updraft or downdraft capable of triggering the valves (i.e. $|w|>w_{T}$ ) in the range of $0.1-20 \mathrm{~s}$, resulting in ambient air sampling in the updraft channel $\left(w>w_{T}\right)$ or in the downdraft channel $\left(w<-w_{T}\right)$. The signals of the two HONO flux traces for the updraft and the downdraft (Fig. 4, upper panels) were lower than that for ambient concentration channel since the flux valves opened to the ambi- ent air only fractions of the time during the 20-min sampling period when $|w|>w_{T}$.

To quantify the amount of HONO collected in each channel during each sampling period, the area of the signal above the "zero-HONO" air baseline was integrated and converted into moles of HONO sampled based on the calibration curve. The integrated HONO concentration was derived from the moles of HONO divided by the ambient air volume sampled when the valve was triggered. The middle panel in Fig. 4 shows the integrated concentrations in the updraft and downdraft channels along with the standard deviation of vertical wind $\left(\sigma_{w}\right)$ during the sampling cycle. The 20-min averaged HONO flux was then derived from the $\sigma_{w}, \bar{C}_{\mathrm{up}}$ and $\bar{C}_{\mathrm{dn}}$ information in the middle panel using Eq. (1) (lower panel, Fig. 4).

To ensure the data quality, data collected in very calm periods were not used for flux calculation, i.e. when vertical wind below the initial threshold $w_{T}^{\mathrm{o}}$ of $0.1 \mathrm{~m} \mathrm{~s}^{-1}$ for more than $95 \%$ of the sampling period. The flux values were usually low during very calm periods, due to the small $\sigma_{w}$. The overall precision is estimated to be within $\pm\left(8 \times 10^{-8}+\right.$ $\left.0.15 F_{\mathrm{HONO}}\right) \mathrm{mol} \mathrm{m}^{-2} \mathrm{~h}^{-1}$, estimated from uncertainties associated with HONO measurements in both up and down channels, the volume of ambient air collected during the periods when the valve was triggered $\left(w>w_{T}\right.$ for the updraft channel and $w<-w_{T}$ for the downdraft channel), and the $\sigma_{w}$ derived from vertical measurement.

An REA-HONO system has been recently reported (Ren et al., 2011), based on the same principles. However, there were several differences in the HONO measurement setups, which might affect the system performance. In our system, the "zero-HONO" air was generated by pulling ambient air through a $\mathrm{NaCO}_{3}$ coated annular denuder and was used to establish a measurement baseline in a 30-min cycle. Since most of the potential interfering species such as $\mathrm{NO}_{\mathrm{x}}$, PAN, nitrate and aerosol pass the denuder (USEPA, 1999), interference from these species was mostly eliminated by subtracting the "zero-HONO" baseline signal from the ambient air signals. Frequent baseline correction under this setup also minimized the HONO measurement uncertainty caused by baseline drift and thus improved measurement accuracy. Furthermore, two dedicated HONO measurement systems were used in the HONO flux measurement, simultaneously measuring HONO concentrations in the updraft and the downdraft air masses within a sampling cycle, with better time resolution.

\subsection{Measurement results}

\subsubsection{Data statistics}

A highlight of the HONO flux measurement results has been published elsewhere (Zhou et al., 2011). A complete data set with discussions of cases is presented here. It should be pointed out first that the actual daytime HONO flux from the forest canopy may be slightly greater than that measured $11 \mathrm{~m}$ above the canopy, owing to the photolytic loss 
of HONO during diffusive turbulent transport, by an upper limit of $\sim 10 \%$ around noontime, assuming a $J_{\mathrm{HONO}}$ of $\sim 6 \mathrm{~h}^{-1}(\sim 10 \mathrm{~min}$ lifetime $)$ and an eddy diffusivity coefficient $\mathrm{Kz}$ of $\sim 3.6 \times 10^{4} \mathrm{~m}^{2} \mathrm{~h}^{-1}$ (or $\sim 1 \times 10^{5} \mathrm{~cm}^{2} \mathrm{~s}^{-1}$ ). Figure 5 shows HONO fluxes and ambient HONO concentrations during the measurement campaign. Overall, upward HONO fluxes were observed most of the time over the measuring period, with occasional downward fluxes during rain, fog and dew events. An upward maximum of $4.7 \times 10^{-6}$ moles $\mathrm{m}^{-2} \mathrm{~h}^{-1}$ was observed during the day after a high $\mathrm{NO}_{\mathrm{x}}$ and $\mathrm{NO}_{\mathrm{y}}$ event, a downward maximum of about $-2 \times 10^{-6}$ moles $\mathrm{m}^{-2} \mathrm{~h}^{-1}$ during a rain event, with a mean of $0.37 \times 10^{-6}$ moles $\mathrm{m}^{-2} \mathrm{~h}^{-1}$. Ambient HONO concentrations ranged from $10 \mathrm{pptv}$ during rain events to 189 pptv during a pollution event at night, with a mean of 49 pptv. On average, both the HONO flux and ambient concentration exhibited noontime to early afternoon maxima, at $\sim 0.7 \times 10^{-6}$ moles $\mathrm{m}^{-2} \mathrm{~h}^{-1}$ and $\sim 70 \mathrm{pptv}$, respectively. The minimum of the average HONO flux was about $\sim 0.1 \times 10^{-6}$ moles $\mathrm{m}^{-2}$ in the early morning before sunrise, and minimum average HONO concentration was $\sim 20 \mathrm{pptv}$ around the time of sunset (Zhou et al., 2011). On average, the photolysis of HONO contributed about $340 \mathrm{pptv} \mathrm{h}^{-1}$ of $\mathrm{OH}$ production around noontime, similar to those reported for this and other rural sites, between $250-560 \mathrm{pptv} \mathrm{h}^{-1}$ (Acker et al., 2006; Zhang et al., 2009; Zhou et al., 2007).

The only other REA HONO flux measurement in the low$\mathrm{NO}_{\mathrm{x}}$ rural environment was made at the Blodgett Forest site in California (Ren et al., 2011). The reported daytime mean HONO flux, $(-0.014 \pm 0.086) \times 10^{-6}$ moles $^{-2} \mathrm{~h}^{-1}$, was much lower than and in the opposite direction to that observed at the PROPHET site. The difference in HONO fluxes at the two rural and forested sites may largely be attributed to the difference in acidity/pH of canopy surfaces. The overall $\mathrm{pH}$ in precipitation in the western US including California is significantly higher than in the mid-western and northeast US, by about $2 \mathrm{pH}$ units (National Atmospheric Deposition Program (NADP), http://nadp.sws.uiuc.edu). While the precipitation $\mathrm{pH}$ does not reflect the actual canopy acidity, it provides useful contract between the two regions. Low industrial $\mathrm{SO}_{2}$ and high agricultural $\mathrm{NH}_{3}$ emissions in California result in relatively low aerosol acidity and thus relatively neutral $\mathrm{pH}$ on canopy surface as well as in precipitation (at or slightly above $\mathrm{pH} 5.5$ controlled by $\mathrm{CO}_{2}$ buffer system). On the other hand, high industrial $\mathrm{SO}_{2}$ emission in the Midwest results in excess acidity in aerosols (mainly as $\mathrm{HSO}_{4}^{-}$) and precipitation ( $\mathrm{pH} 3-4.7)$, and thus acidify the canopy surface. Since HONO is a weak acid, with a pKa of 3.5, the HONOnitrite equilibrium would shift to nitrite with higher $\mathrm{pH}$. At elevated $\mathrm{pH}$, canopy and ground surfaces may sometimes behave more like a sink than a source for HONO at the Blodgett Forest site (Ren et al., 2010, 2011). In the Mid West and Northeast, on the other hand, HONO can be readily released into the atmosphere from acidic canopy and ground surfaces once produced (He et al., 2006), and becomes a major HONO

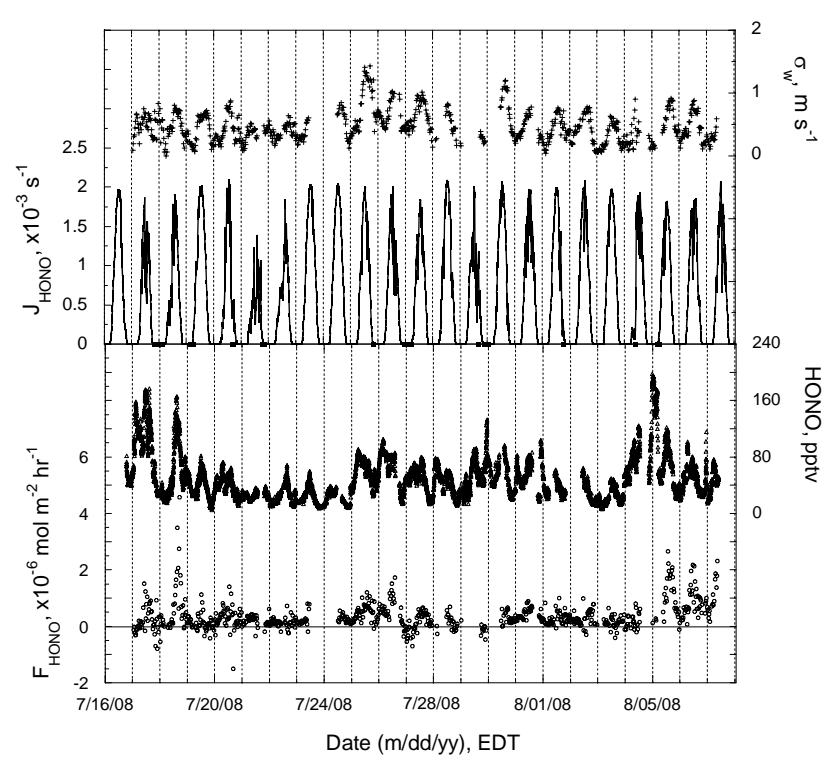

Fig. 5. Time-series of HONO flux (open circles, lower panel, left axis), ambient HONO concentration (open triangles, lower panel, right axis), $J_{\mathrm{HONO}}$ (line, upper panel, left axis), and $\sigma_{w}$ (cross, upper panel, right axis). The thick horizontal lines at the bottom of the upper panel indicate the periods of rain, mist/fog, or dew events.

source for the overlying atmosphere (He et al., 2006; Zhou et al., 2002a, 2007, 2011). In addition, the surface $\mathrm{pH}$ has strong effect on the photolysis rate of surface $\mathrm{HNO}_{3}$ (or nitrate) as a HONO source. Laboratory results have shown that photolysis rate is much slower for nitrate salt than $\mathrm{HNO}_{3}$ on surfaces, e.g. by a factor of $>10$ for $\mathrm{NaNO}_{3}$ compared to $\mathrm{HNO}_{3}$ on Pyrex surface (Zhou et al., 2007; Gao, 2011). Photolysis potential of deposited $\mathrm{HNO}_{3}$ on canopy surface, defined as the product of surface nitrate loading and the surface nitrate photolysis rate constant, $J_{\mathrm{s}-\mathrm{HNO}_{3}} \times L_{\text {nitrate }}$, has been found to strongly correlated to the upward HONO flux at the PROPHET site, suggesting that photolysis of surface $\mathrm{HNO}_{3}$ is the major daytime HONO source at this site (Zhou et al., 2011). However, this process might not be that important at the Blodgett Forest site (Ren et al., 2011) due to much slower nitrate photolysis on the surface at or near neutral $\mathrm{pH}$.

\subsubsection{Forest canopy as a HONO source or a sink}

In forested areas, forest canopy surfaces account for the majority of the surface area in the atmospheric boundary layer, thus serve as sites for the heterogeneous reaction leading to HONO formation under favorable conditions. Indeed, the canopy was a net source for HONO at the PROPHET site most of the time indicated by the observed upward HONO flux (Fig. 5). However, the canopy can also be a net HONO sink, as indicated by occasional downward fluxes during rain events (e.g. 17, 20, 29 July), and fog and dew events (e.g. 19, 27 July) (Fig. 5). The wet canopy seemed to enhance the 
dry deposition of $\mathrm{HONO}$ and/or prevent HONO from being released once produced by heterogeneous reactions, in agreement with previous observations (e.g. Zhou et al., 2002a; He et al., 2006).

Figure 6 shows the effect of vertical wind variability on HONO transport. On average, HONO concentrations were about $8 \%$ higher in the updraft air than in the downdraft air, with increasing variability at lower $\sigma_{w}$. Lower $\sigma_{w}$ tended to occur during the night (Fig. 5) when the air was more stable due to surface cooling. During the nights that were free of rain or dew, the canopy surface would act as a HONO source, and steeper negative vertical HONO gradients would develop under stagnant conditions, resulting in positive spreads in the HONO concentration difference (He et al., 2006; Zhou et al., 2011). However, dew and mist events occurred in some calm and clear nights, and dry deposition of HONO was enhanced by the wet canopy, resulting in the negative spread of HONO concentration difference (Fig. 6) (He et al., 2006; Zhou et al., 2011). There is a general trend of higher HONO flux with higher $\sigma_{w}$, as expected from Eq. (1). However, the maximum fluxes, both upward and downward, occurred at the mid range $\sigma_{w}$ values. The highest upward fluxes occurred around solar noon during the days after passing urban plumes deposited HONO precursors on the canopy, for example, on 18 July and 5 August (see more discussion in Case Study below). The highest downward fluxes occurred during a thunder storm in the afternoon of 20 July (Fig. 5).

Substantial levels of HONO existed during the day, despite the effective photolytic loss, reaching an average maximum of about $70 \mathrm{pptv}$ around solar noon. To sustain the observed concentration, a strong HONO source, about $350 \mathrm{pptv} \mathrm{h}^{-1}$ on average around noontime, was needed. Zhou et al. (2011) estimated the effect of canopy surface on the observed HONO mixing ratios, based on a 1-D transport of HONO from the canopy. The midday HONO flux of $\sim 0.7 \times 10^{-6}$ moles $\mathrm{m}^{-2} \mathrm{~h}^{-1}$ accounted for the majority of the observed HONO, $\sim 57 \%$ on average, at the observation height of $11 \mathrm{~m}$ above canopy, assuming a HONO photolysis rate constant of $\sim 5 \mathrm{~h}^{-1}$ and a eddy diffusivity coefficient $(K z)$ of $\sim 3.6 \times 10^{4} \mathrm{~m}^{2} \mathrm{~h}^{-1}$ ( or $\sim 1 \times 10^{5} \mathrm{~cm}^{2} \mathrm{~s}^{-1}$ ). The remaining $43 \%$ was from homogeneous and heterogeneous HONO production mechanisms in the air column, such as gaseous NO-OH reactions, and photo-enhanced heterogeneous reactions involving $\mathrm{NO}_{\mathrm{x}}$ and $\mathrm{HNO}_{3}$ on aerosol surface.

\subsubsection{HONO precursors}

It is generally believed that atmospheric HONO is produced mostly by heterogeneous reactions involving HONO precursors such as $\mathrm{NO}_{\mathrm{x}}$ (George et al., 2005; Lammel and Cape, 1996; Stemmler et al., 2006, 2007; Ren et al., 2011) and $\mathrm{HNO}_{3}$ (Zhou et al., 2002a, 2002b, 2003, 2007, 2011). In low- $\mathrm{NO}_{\mathrm{x}}$ environments, photolysis of $\mathrm{HNO}_{3}$ deposited on ground/canopy surface has been proposed to be the major

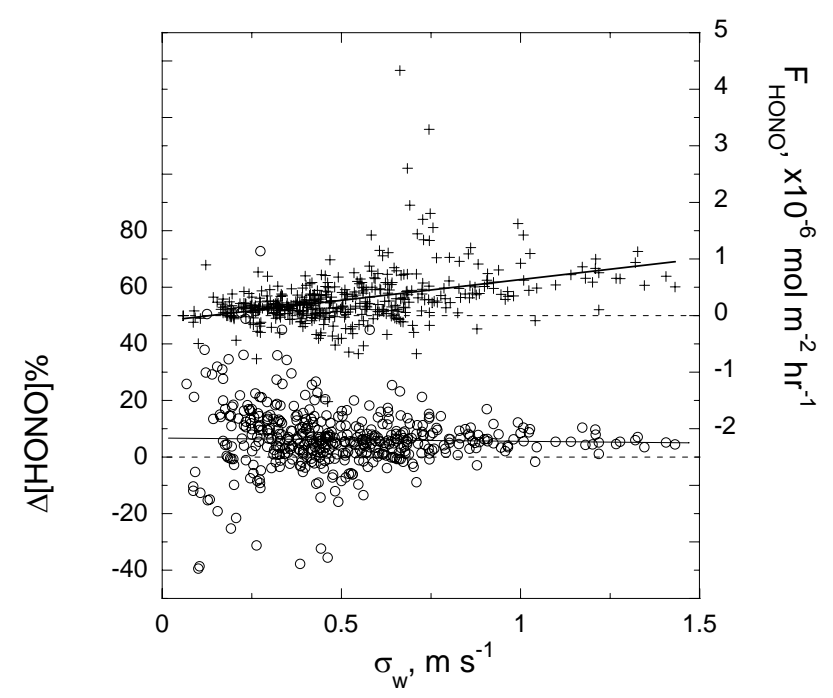

Fig. 6. The percentage difference between HONO concentrations (open circles, left axis) in the updraft and downdraft air masses and HONO flux (crosses, right axis) as functions of standard deviation of vertical wind speed.

daytime HONO source (Zhou et al., 2002a, 2003, 2007). To test this hypothesis, 16 sets of leaf samples (6 leaves per set) were collected at the top of the forest canopy for surface nitrate measurement (Zhou et al., 2011). The daytime HONO flux was found to be strongly correlated $\left(r^{2}=0.69\right)$ with the surface nitrate photolysis potential, $J_{\mathrm{s}-\mathrm{HNO}_{3}} \times L_{\text {nitrate }}$. Therefore, it was concluded that photolysis of $\mathrm{HNO}_{3}$ deposited on the canopy surface was the major mechanism responsible for the observed daytime HONO flux from the canopy into the atmosphere (details see Zhou et al., 2011).

During the recent California Research at the Nexus of Air Quality and Climate Change (CalNex 2010) study, a very strong positive correlation $\left(r^{2}=0.985\right)$ was observed between $\mathrm{HONO}$ flux and the product of $\mathrm{NO}_{2}$ concentration and solar radiation at Bakersfield site (Ren et al., 2011), suggesting that photo-enhanced $\mathrm{NO}_{2}$ reactions on ground surface was the dominant $\mathrm{HONO}$ source. In this study, the concentrations of $\mathrm{NO}_{\mathrm{x}}$ and $\mathrm{HONO}$, and the HONO flux were measured simultaneously over two weeks, allowing us to examine the role of $\mathrm{NO}_{\mathrm{x}}$ as a $\mathrm{HONO}$ precursor at this site. During the day, poor and slight negative correlations were found between $\left[\mathrm{NO}_{\mathrm{x}}\right]$ and the HONO flux $\left(r^{2}=0.01\right.$, Fig. 7) and between HONO flux and $\left[\mathrm{NO}_{2}\right] \times J_{\mathrm{NO}_{2}}\left(r^{2}=0.01\right)$, suggesting that $\mathrm{NO}_{\mathrm{x}}$ was not a significant daytime $\mathrm{HONO}$ precursor responsible for the upward flux from the forest canopy. $\mathrm{NO}_{\mathrm{x}}$ was far less important as a precursor for HONO at the PROPHET site compared to Bakersfield site, as a result of a significantly lower $\mathrm{NO}_{\mathrm{x}}$ level (mean noontime $\left[\mathrm{NO}_{\mathrm{x}}\right] \sim 0.6 \mathrm{ppbv}$ vs. 3 ppbv) (Ren et al., 2011). In addition, higher photolysis rate of the deposited $\mathrm{HNO}_{3}$ and nitrate on more acidic canopy surface (Gao, 2011) made it a more important HONO 


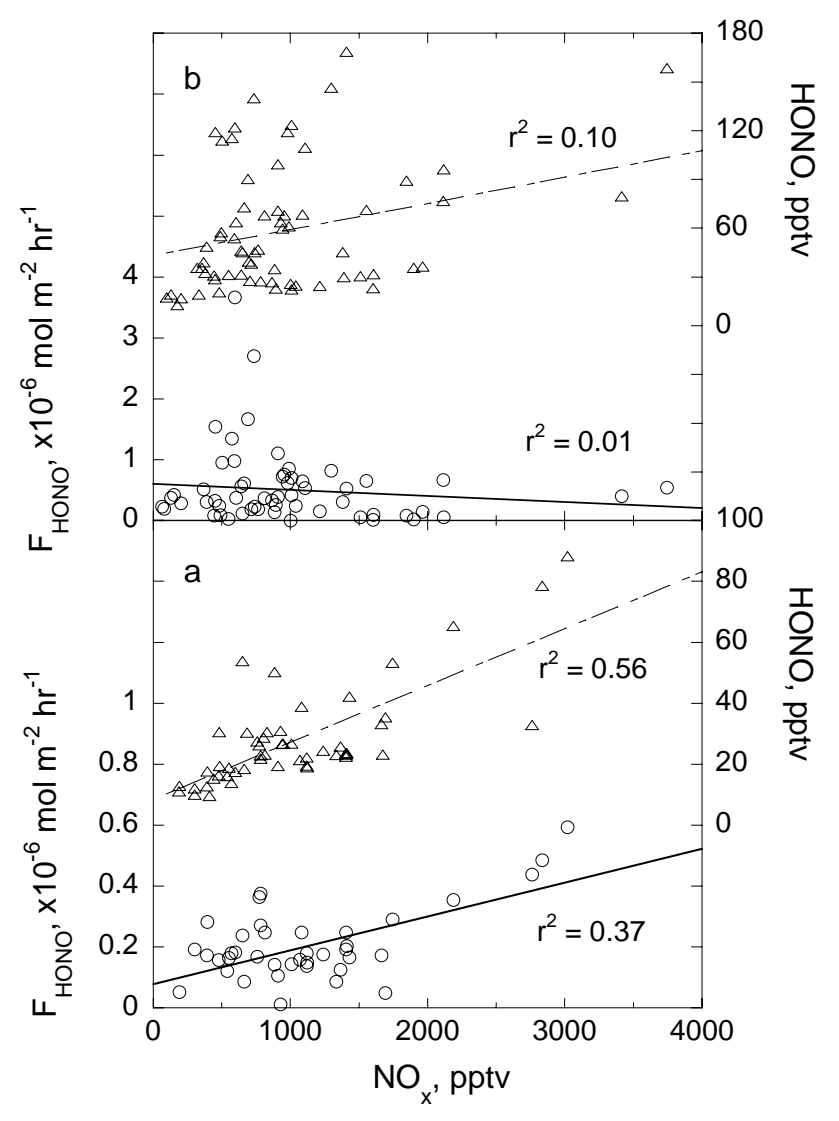

Fig. 7. Correlations between the HONO flux (left axis, open circles) and ambient $\mathrm{NO}_{\mathrm{x}}$ concentrations, and between ambient HONO (right axis, open triangles) and $\mathrm{NO}_{\mathrm{x}}$ concentrations during the night (22:00-06:00 EDT, (a) and during the day (08:00-18:00 EDT, (b). The data are hourly averages, excluding the rain, fog and dew events. The lines are the least-square fits for the data.

source at the PROPHET site than at Bakersfield site (see discussion in Sect. 3.3.1). The correlation between $\left[\mathrm{NO}_{\mathrm{x}}\right]$ and daytime [HONO] was positive and slightly improved but still weak $\left(r^{2}=0.10\right)$, reflecting some degree of contribution from the volume HONO production under occasional high$\mathrm{NO}_{\mathrm{x}}$ conditions during southerly flows.

During the nights that were free of rain or dew, the contribution of the dark heterogeneous $\mathrm{NO}_{\mathrm{x}}$ reactions on canopy surface to the observed HONO flux increased, as indicated by the improved and positive correlation between HONO flux and $\left[\mathrm{NO}_{\mathrm{x}}\right]\left(r^{2}=0.37\right.$, Fig. 7). The further improved and moderate correlation between $[\mathrm{HONO}]$ and $\left[\mathrm{NO}_{\mathrm{x}}\right]\left(r^{2}=\right.$ 0.56 , Fig. 7) indicates the contributions to the observed HONO from both local production on forest surfaces and the transport in the air mass, and suggests that $\mathrm{NO}_{\mathrm{x}}$ was the major HONO precursor when photolysis of $\mathrm{HNO}_{3}$ on surface was absent.

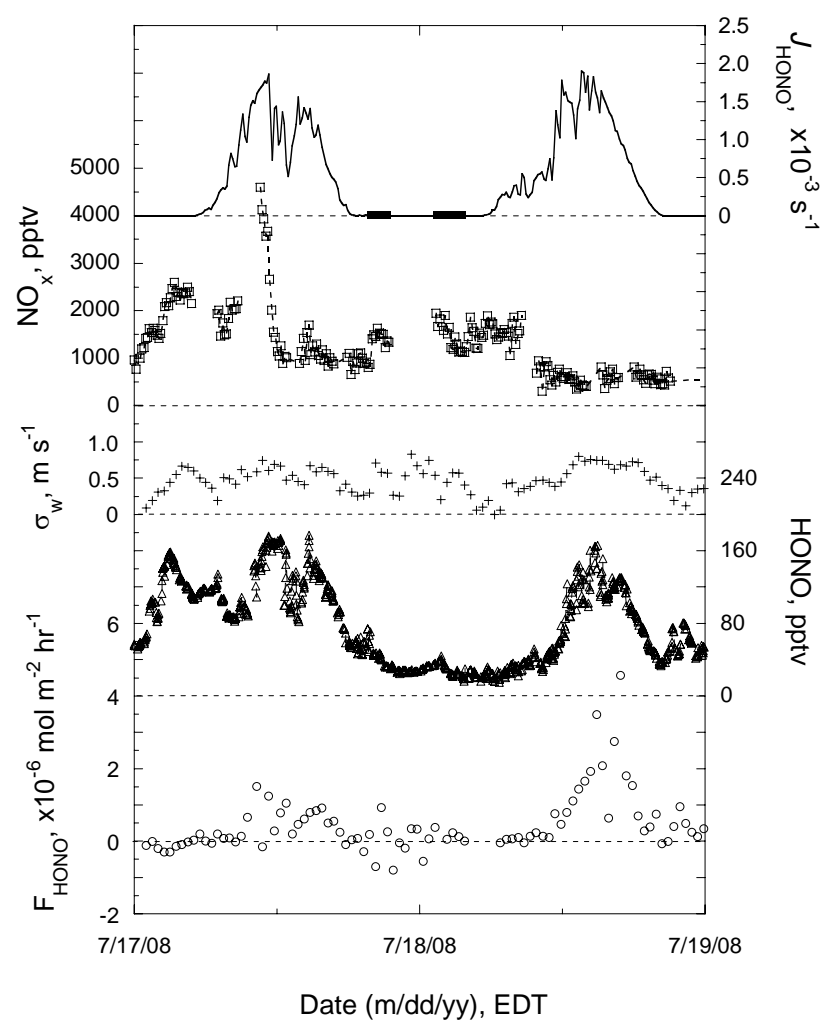

Fig. 8. Two days of time-series of HONO flux (open circles, lower panel, left axis), ambient HONO concentration (open triangles, lower panel, right axis), $\sigma_{w}$ (crosses) and $\mathrm{NO}_{\mathrm{x}}$ (open squares, upper panel, left axis), and $J_{\mathrm{HONO}}$ (line, upper panel, right axis). The two thick horizontal lines at $J_{\mathrm{HONO}}=0$ in the upper panel indicate two periods of light rain.

\subsubsection{A case study}

The behavior of HONO during the initial two days of this campaign is examined in more detail to illustrate the processes discussed above as a case study (Fig. 8). During the morning of 17 July, the concentrations of $\mathrm{HONO}$ and $\mathrm{NO}_{\mathrm{x}}$ varied in sync when air masses switched from clean northwesterly flow to more polluted southwesterly flow before sunrise. Both $\mathrm{HONO}$ and $\mathrm{NO}_{\mathrm{x}}$ concentrations were rising rapidly, from $\sim 40$ pptv to $\sim 160 \mathrm{pptv}$ and from $\sim 700 \mathrm{pptv}$ to $\sim 2600 \mathrm{pptv}$, respectively. The strong and positive correlation between the concentrations of $\mathrm{HONO}$ and $\mathrm{NO}_{\mathrm{x}}\left(r^{2}=0.89\right.$, $N=7$, hourly averages) and the slightly downward HONO flux during the early morning period suggests that the observed ambient HONO during the period was transported within the air mass, with $\mathrm{NO}_{\mathrm{x}}$ as the dominant HONO precursor.

After sunrise, the HONO flux was mostly positive (up to $\sim 1.7 \times 10^{-6}$ moles $\mathrm{m}^{-2} \mathrm{~h}^{-1}$ ), with the exception of a slightly negative flux $\left(\sim-0.1 \times 10^{-6}\right.$ moles $\left.\mathrm{m}^{-2} \mathrm{~h}^{-1}\right)$ at 11:30 EDT when $\left[\mathrm{NO}_{\mathrm{x}}\right]$ reached a peak of $4500 \mathrm{pptv}$. Several similar brief negative HONO fluxes occurred throughout 
the campaign, mostly coinciding with rapid increase in $\mathrm{NO}_{\mathrm{x}}$ and with relatively high ambient HONO concentrations. This phenomenon may be caused by the deposition of HONO at an elevated concentration and mixing of the more polluted air aloft with the relatively clean air within the forest canopy during the early and rapid-changing phase of pollution episode.

In the afternoon, the HONO flux remained significantly positive, between 0.1 and $1.1 \times 10^{-6}$ moles $^{-2} \mathrm{~h}^{-1}$ despite the significant decrease in $\mathrm{NO}_{\mathrm{x}}$ to around 1000 pptv. Furthermore, both the HONO flux and ambient HONO concentrations seemed to modulate with the fluctuation of HONO photolysis rate constant, suggesting significant contribution of photochemical production of HONO at the forest canopy to the overlying atmosphere.

Light rain and drizzle started around 08:00 p.m. (EDT) and continued intermittently throughout the night, as indicated by the thick line on the x-axis of the upper panel in Fig. 8. When surfaces were wet, the forest canopy became a sink rather than a source for HONO (He et al., 2006; Zhou et al., 2011). As a result, the net HONO flux was negative, and ambient HONO concentrations remained low, mostly within 20 $30 \mathrm{pptv}$. However, there was significant fluctuation in HONO flux before and around midnight, probably due to high wind variability during this period. The following period (04:0007:00 EDT) was very calm with the vertical wind speed $w$ lower than the threshold $w_{\mathrm{t}}$ value of $0.1 \mathrm{~m} \mathrm{~s}^{-1}$ (Fig. 5), resulting in a data gap in HONO flux.

There were intermittent clouds in the morning of 18 July; both HONO flux and ambient HONO concentrations remained low. The sky became clear shortly after noontime; both the HONO flux and ambient HONO concentration started to increase, reaching a HONO flux maximum of $4.6 \times 10^{-6}$ moles $\mathrm{m}^{-2} \mathrm{~h}^{-1}$ and a daytime HONO concentration maximum of $165 \mathrm{pptv}$ in the early to mid afternoon. It is especially worthy to point out that the air arriving at the site had changed from southwesterly (polluted) to northwesterly (clean) in the mid morning, with $\left[\mathrm{NO}_{\mathrm{x}}\right]$ dropping from $\sim 1500$ pptv to $\sim 400$ pptv. This anti-correlation between $\mathrm{NO}_{\mathrm{x}}$ and $\mathrm{HONO}$ flux suggests that ambient $\mathrm{NO}_{\mathrm{x}}$ was not a significant precursor for the HONO produced at the canopy surface. During the southwesterly flow period during the previous day and night, $\mathrm{HNO}_{3}$ as well as organics might have deposited from the "dirty" southwesterly air mass and accumulated on the leaf surfaces at the top of forest canopy. When exposed to solar UV radiation, the photolysis of the deposited $\mathrm{HNO}_{3}$ (Zhou et al., 2003, 2011), enhanced by the presence of organics (Zhang, 2011), was probably the dominant HONO production mechanism responsible for the higher upward flux and the high ambient HONO concentration.

The HONO flux as well as the ambient HONO concentration decreased in the late afternoon and evening as the solar radiation and the photolytic HONO source decreased. There were, however, some spikes in HONO flux and HONO concentration before midnight, probably associated with a change in air masses. Indeed, the back trajectory calculation indicates that air flow changed from northwesterly to southwesterly and then back to northwesterly during the $\sim 4 \mathrm{~h}$ before midnight.

\section{Summary and conclusions}

1. A HONO measurement method (Huang et al., 2002; He et al., 2006) has been modified and improved, based on aqueous scrubbing of HONO using a coil sampler, followed by azo dye derivatization and LPAP detection using an optical fiber spectrometer with a 1-m long path flow cell. A $\mathrm{Na}_{2} \mathrm{CO}_{3}$-coated denuder is used to generate "zero HONO" air for background correction. The lower detection limit of the method, as defined by 3 times the standard deviation of the signal, is $1 \mathrm{pptv}$ for 1 -min averages, with an overall uncertainty of $\pm(1+$ 0.05 [HONO]) pptv.

2. A HONO flux measurement technique has been developed based on the relaxed eddy accumulation approach, using a 3-D sonic anemometer and two HONO measurement systems. The overall precision is estimated to be within $\pm\left(8 \times 10^{-8}+0.15 F_{\mathrm{HONO}}\right) \mathrm{mol} \mathrm{m}^{-2} \mathrm{~h}^{-1}$, with 20-min averaged data point per $30 \mathrm{~min}$.

3. The techniques for ambient HONO and HONO flux measurements have been successfully deployed at the PROPHET site during the summer of 2008. The mean HONO concentration was 49 pptv. The forest canopy was a net HONO source for the overlying atmosphere, with a mean HONO flux was $0.37 \times 10^{-6}$ moles $\mathrm{m}^{-2} \mathrm{~h}^{-1}$, a maximal mean of $\sim 0.7 \times 10^{-6}$ moles $\mathrm{m}^{-2} \mathrm{~h}^{-1}$ in the early afternoon, and a minimal mean of $\sim 0.1 \times 10^{-6}$ moles $\mathrm{m}^{-2}$ in the early morning before sunrise.

4. During the day, $\mathrm{NO}_{\mathrm{x}}$ was not an important $\mathrm{HONO}$ precursor at this low- $\mathrm{NO}_{\mathrm{x}}$ site, as indicated by the poor and negative correlations between HONO flux and $\left[\mathrm{NO}_{\mathrm{x}}\right]\left(r^{2}=0.01\right)$, and between HONO flux and $J_{\mathrm{NO}_{2}} \times\left[\mathrm{NO}_{2}\right]\left(r^{2}=0.01\right)$. Photolysis of $\mathrm{HNO}_{3}$ deposited on the top of canopy was probably the major daytime HONO source (Zhou et al., 2011).

5. During the night, both local production on forest surfaces and the transport in the air mass contributed to the observed $\mathrm{HONO}$ at this site, with $\mathrm{NO}_{\mathrm{x}}$ as the major HONO precursor, as suggested by the moderate and positive correlations between $\mathrm{HONO}$ flux and $\left[\mathrm{NO}_{\mathrm{x}}\right]$ $\left(r^{2}=0.37\right)$ and between [HONO] and $\left[\mathrm{NO}_{\mathrm{x}}\right]\left(r^{2}=\right.$ $0.56)$. 
Acknowledgements. We thank fellow PROPHETeers for their assistance and University of Michigan Biological Station for outstanding logistical support during the field deployments. This research was supported by National Science Foundation ATM0632548 .

Edited by: A. Hofzumahaus

\section{References}

Acker, K., Spindler, G., and Bruggemann, E.: Nitrous and nitric acid measurements during the INTERCOMP2000 campaign in Melpitz, Atmos. Environ., 38, 6497-6505, 2004.

Acker, K., Moller, D., Wieprecht, W., Meixner, F. X., Bohn, B., Gilge, S., Plass-Dulmer, C., and Berresheim, H.: Strong daytime production of $\mathrm{OH}$ from $\mathrm{HNO}_{2}$ at a rural mountain site, Geophys. Res. Lett., 33, L02809, doi:10.1029/2005GL024643, 2006.

Alaghmand, M., Shepson, P. B., Starn, T. K., Jobson, B. T., Wallace, H. W., Carroll, M. A., Bertman, S. B., Lamb, B., Edburg, S. L., Zhou, X., Apel, E., Riemer, D., Stevens, P., and Keutsch, F.: The Morning NO x maximum in the forest atmosphere boundary layer, Atmos. Chem. Phys. Discuss., 11, 2925129282, doi:10.5194/acpd-11-29251-2011, 2011.

Alicke, B., Platt, U., and Stutz, J.: Impact of nitrous acid photolysis on the total hydroxyl radical budget during the Limitation of Oxidant Production/Pianura Padana Produzione di Ozono study in Milan, J. Geophys. Res., 107, 8196, doi:10.1029/2000JD000075, 2002.

Alicke, B., Geyer, A., Hofzumahaus, A., Holland, F., Konrad, S., Patz, H. W., Schafer, J., Stutz, J., Volz-Thomas, A., and Platt, U.: $\mathrm{OH}$ formation by HONO photolysis during the BERLIOZ experiment, J. Geophys. Res., 108, 8247, doi:10.1029/2001JD000579, 2003.

Ammann, C., Brunner, A., Spirig, C., and Neftel, A.: Technical note: Water vapour concentration and flux measurements with PTR-MS, Atmos. Chem. Phys., 6, 4643-4651, doi:10.5194/acp6-4643-2006, 2006.

Beine, H. J., Amoroso, A., Esposito, G., Sparapani, R., Ianniello, A., Georgiadis, T., Nardino, M., Bonasoni, P., Cristofanelli, P., and Domine, F.: Deposition of atmospheric nitrous acid on alkaline snow surfaces, Geophys. Res. Lett., 32, L10808, doi:10.1029/2005GL022589, 2005.

Beine, H. J., Amoroso, A., Dominé, F., King, M. D., Nardino, M., Ianniello, A., and France, J. L.: Surprisingly small HONO emissions from snow surfaces at Browning Pass, Antarctica, Atmos. Chem. Phys., 6, 2569-2580, doi:10.5194/acp-6-2569-2006, 2006.

Bowling, D. R., Turnipseed, A. A., Delany, A. C., Baldocchi, D. D., Greenberg, J. P., and Monson, R. K.: The use of relaxed eddy accumulation to measure biosphere-atmosphere exchange of isoprene and of her biological trace gases, Oecologia, 116, 306-315, 1998.

Bröske, R., Kleffmann, J., and Wiesen, P.: Heterogeneous conversion of $\mathrm{NO}_{2}$ on secondary organic aerosol surfaces: A possible source of nitrous acid (HONO) in the atmosphere?, Atmos. Chem. Phys., 3, 469-474, doi:10.5194/acp-3-469-2003, 2003.

Businger, J. A. and Oncley, S. P.: Flux Measurement with Conditional Sampling, J. Atmos. Ocean. Tech., 7, 349-352, 1990.
Carroll, M. A., Bertman, S. B., and Shepson, P. B.: Overview of the Program for Research on Oxidants: PHotochemistry, Emissions, and Transport (PROPHET) summer 1998 measurements intensive, J. Geophys. Res., 106, 24275-24288, doi:10.1029/2001JD900189, 2001.

Chahuneau, F., Desjardins, R. L., Brach, E., and Verdon, R.: A Micrometeorological Facility for Eddy Flux Measurement of $\mathrm{CO}_{2}$ and $\mathrm{H}_{2} \mathrm{O}$, J. Atmos. Ocean. Tech., 6, 193-200, 1989.

Cooper, O. R., Moody, J. L., Thornberry, T. D., Town, M. S., and Carroll, M. A.: PROPHET 1998 meteorological overview and air-mass classification, J. Geophys. Res., 106, 24289-24300, doi:10.1029/2000JD900409, 2001.

Draxler, R. R. and Rolph, G. D.: HYSPLIT (HYbrid Single-Particle Lagrangian Integrated Trajectory) Model access via NOAA ARL READY Website (http://www.arl.noaa.gov/ready/hysplit4.html), NOAA Air Resources Laboratory, Silver Spring, MD, 2003.

Elshorbany, Y. F., Kleffmann, J., Kurtenbach, R., Rubio, M., Lissi, E., Villena, G., Gramsch, E., Rickard, A. R., Pilling, M. J., and Wiesen, P.: Summertime photochemical ozone formation in Santiago, Chile, Atmos. Environ., 43, 6398-6407, 2009.

Galmarini, S., DeArellano, J. V. G., and Duyzer, J.: Fluxes of chemically reactive species inferred from mean concentration measurements, Atmos. Environ., 31, 2371-2374, 1997.

Gao, H.: Significance of Nitric Acid Photolysis on Surfaces in Tropospheric Chemistry, Ph.D. Thesis, State University of New York at Albany, ISBN: 9781124702780, 144 pp., 2011.

George, C., Strekowski, R. S., Kleffmann, J., Stemmler, K., and Ammann, M.: Photoenhanced uptake of gaseous $\mathrm{NO}_{2}$ on solid organic compounds: a photochemical source of HONO?, Faraday Discuss., 130, 195-210, 2005.

Grassian, V. H.: Chemical reactions of nitrogen oxides on the surface of oxide, carbonate, soot, and mineral dust particles: Implications for the chemical balance of the troposphere, J. Phys. Chem. A, 106, 860-877, 2002.

Harrison, R. M. and Kitto, A.-M. N.: Evidence for a surface source of atmospheric nitrous acid, Atmos. Environ., 28, 1089-1094, 1994.

He, Y., Zhou, X., Hou, J., Gao, H., and Bertman, S. B.: Importance of dew in controlling the air-surface exchange of HONO in rural forested environments, Geophys. Res. Lett., 33, L02813, doi:10.1029/2005GL024348, 2006.

Honrath, R. E., Lu, Y., Peterson, M. C., Dibb, J. E., Arsenault, M. A., Cullen, N. J., and Steffen, K.: Vertical fluxes of $\mathrm{NO}_{\mathrm{X}}, \mathrm{HONO}$, and $\mathrm{HNO}_{3}$ above the snowpack at Summit, Greenland, Atmos. Environ., 36, 2629-2640, 2002.

Huang, G., Zhou, X., Deng, G., Qiao, H., and Civerolo, K.: Measurements of atmospheric nitrous acid and nitric acid, Atmos. Environ., 36, 2225-2235, 2002.

Kleinman, L., Lee, Y.-N., Springston, S. R., Lee, J. H., Nunnermacker, L., Weinsten-Lloyd, J., Zhou, X., and Newman L.: Peroxy radical concentration and ozone formation rate at a rural site in southeastern United States, J. Geophys. Res., 100, 7263-7273, 1995.

Kleffmann, J. and Wiesen, P.: Heterogeneous conversion of $\mathrm{NO}_{2}$ and $\mathrm{NO}$ on $\mathrm{HNO}_{3}$ treated soot surfaces: atmospheric implications, Atmos. Chem. Phys., 5, 77-83, doi:10.5194/acp-5-772005, 2005.

Kleffmann, J., Kurtenbach, R., Lorzer, J., Wiesen, P., Kalthoff, N., Vogel, B., and Vogel, H.: Measured and simulated vertical pro- 
files of nitrous acid - Part I: Field measurements, Atmos. Environ., 37, 2949-2955, 2003.

Kleffmann, J., Gavriloaiei, T., Hofzumahaus, A., Holland, F., Koppmann, R., Rupp, L., Schlosser, E., Siese, M., and Wahner, A.: Daytime formation of nitrous acid: A major source of $\mathrm{OH}$ radicals in a forest, Geophys. Res. Lett., 32, L05818, doi:10.1029/2005GL022524, 2005.

Lammel, G. and Cape, J. N.: Nitrous acid and nitrite in the atmosphere, Chem. Soc. Rev., 25, 361-369, 1996.

Ndour, M., D’Anna, B., George, C., Ka, O., Balkanski, Y., Kleffmann, J., Stemmler, K., and Ammann, M.: Photoenhanced uptake of $\mathrm{NO}_{2}$ on mineral dust: Laboratory experiments and model simulations, Geophys. Res. Lett., 35, L05812, doi:10.1029/2007GL032006, 2008.

Oncley, S. P., Delany, A. C., Horst, T. W., and Tans, P. P.: Verification of flux measurement using relaxed eddy accumulation, Atmos. Environ., 27, 2417-2426, 1993.

Pattey, E., Desjardins, R. L., and Rochette, P.: Accuracy of the relaxed eddy-accumulation technique, evaluated using $\mathrm{CO}_{2}$ flux measurements, Bound.-Lay. Meteorol., 66, 341-355, 1993.

Ren, X., Brune, W. H., Oliger, A., Metcalf, A. R., Simpas, J. B., Shirley, T., Schwab, J. J., Bai, C., Roychowdhury, U., Li, Y., Cai, C., Demerjian, K. L., He, Y., Zhou, X., Gao, H., and Hou, J.: $\mathrm{OH}, \mathrm{HO}_{2}$, and $\mathrm{OH}$ reactivity during the PMTACS-NY Whiteface Mountain 2002 campaign: observations and model comparison, J. Geophys. Res., 111, D10S03, doi:10.1029/2005JD006126, 2006.

Ren, X., Gao, H., Zhou, X., Crounse, J. D., Wennberg, P. O., Browne, E. C., LaFranchi, B. W., Cohen, R. C., McKay, M., Goldstein, A. H., and Mao, J.: Measurement of atmospheric nitrous acid at Bodgett Forest during BEARPEX2007, Atmos. Chem. Phys., 10, 6283-6294, doi:10.5194/acp-10-6283-2010, 2010.

Ren, X., Sanders, J. E., Rajendran, A., Weber, R. J., Goldstein, A. H., Pusede, S. E., Browne, E. C., Min, K.-E., and Cohen, R. C.: A relaxed eddy accumulation system for measuring vertical fluxes of nitrous acid, Atmos. Meas. Tech., 4, 2093-2103, doi:10.5194/amt-4-2093-2011, 2011.

Ridley, B. A. and Grahek, F. E.: A small, low flow, high-sensitivity reaction vessel for NO chemiluminescence detectors, J. Atmos. Ocean. Tech., 7, 307-311, 1990.

Stemmler, K., Ammann, M., Donders, C., Kleffmann, J., and George, C.: Photosensitized reduction of nitrogen dioxide on humic acid as a source of nitrous acid, Nature, 440, 195-198, 2006.

Stemmler, K., Ndour, M., Elshorbany, Y., Kleffmann, J., D’Anna, B., George, C., Bohn, B., and Ammann, M.: Light induced conversion of nitrogen dioxide into nitrous acid on submicron humic acid aerosol, Atmos. Chem. Phys., 7, 4237-4248, doi:10.5194/acp-7-4237-2007, 2007.

Stutz, J., Alicke, B., and Neftel, A.: Nitrous acid formation in the urban atmosphere: gradient measurements of $\mathrm{NO}_{2}$ and HONO over grass in Milan, Italy, J. Geophys. Res., 107, 8192, doi:10.1029/2001JD000390, 2002.

USEPA publication 625/R-96/010a, Compendium of Methods for the Determination of Inorganic Compounds in Ambient Air: 10-4.2 Determination of Reactive Acidic and Basic Gases and Strong Acidity of Fine Particles, available at: http://www.epa. gov/ttnamti1/, 1999.
Veitel, H., Kromer, B., Mossner, M., and Platt, U.: New techniques for measurements of atmospheric vertical trace gas profiles using DOAS, Environ. Sci. Pollut. Res., 4, 17-26, 2002.

Villena, G., Kleffmann, J., Kurtenbach, R., Wiesen, P., Lissi, E., Rubio, M. A., Croxatto, G., and Rappengluck, B.: Vertical gradients of $\mathrm{HONO}, \mathrm{NO}_{\mathrm{x}}$ and $\mathrm{O}_{3}$ in Santiago de Chile, Atmos. Environ., 45, 3867-3873, 2011.

Vogel, B., Vogel, H., Kleffmann, J., and Kurtenbach, R.: Measured and simulated vertical profiles of nitrous acid - Part II. Model simulations and indications for a photolytic source, Atmos. Environ., 37, 2957-2966, 2003.

Westberg, H., Lamb, B., Hafer, R., Hills, A., Shepson, P., and Vogel, C.: Measurement of isoprene fluxes at the PROPHET site, J. Geophys. Res., 106, 24347-24358, doi:10.1029/2000JD900735, 2001.

Wilczak, M. J., Oncley, S. P, and Stage, S. A.: Sonic Anemometer tilt correction algorithms, Bound. Lay. Meteorol., 99, 127-150, 2001

Zhang, N.: Distributions and Sources of HONO in the Rural Troposphere, Ph.D. Thesis, State University of New York at Albany, ISBN: 9781267091130, 156 pp., 2011.

Zhang, N., Zhou, X. L., Shepson, P. B., Gao, H. L., Alaghmand, M., and Stirm, B.: Aircraft measurement of HONO vertical profiles over a forested region, Geophys. Res. Lett., 36, L15820, doi:10.1029/2009GL038999, 2009.

Zhou, X. L., Beine, H. J., Honrath, R. E., Fuentes, J. D., Simpson, W., Shepson, P. B., and Bottenheim, J. W.: Snowpack photochemical production of HONO: a major source of $\mathrm{OH}$ in the Arctic boundary layer in springtime, Geophys. Res. Lett., 28, 4087-4090, doi:10.1029/2001GL013531, 2001.

Zhou, X., Civerolo, K., Dai, H., Huang, G., Schwab, J., and Demerjian, K.: Summertime nitrous acid chemistry in the atmospheric boundary layer at a rural site in New York State, J. Geophys. Res., 107, 4590, doi:10.1029/2001JD001539, 2002a.

Zhou, X., He, Y., Huang, G., Thornberry, T. D., Carroll, M. A., and Bertman, S. B.: Photochemical production of nitrous acid on glass sample manifold surface, Geophys. Res. Lett., 29, 1681, doi:10.1029/2002GL015080, 2002b.

Zhou, X., Gao, H., He, Y., Huang, G., Bertman, S. B., Civerolo, K., and Schwab, J.: Nitric acid photolysis on surfaces in lowNOx environments: significant atmospheric implications, Geophys. Res. Lett., 30, 2217, doi:10.1029/2003GL018620, 2003.

Zhou, X., Huang, G., Civerolo, K., Roychowdhury, U., and Demerjian, K. L.: Summertime observations of $\mathrm{HONO}, \mathrm{HCHO}$, and $\mathrm{O}_{3}$ at the summit of Whiteface Mountain, New York, J. Geophys. Res., 112, D08311, doi:10.1029/2006JD007256, 2007.

Zhou, X., Zhang, N., Michaela, T., Tang, D., Hou, J., Bertman, S. B., Alaghmand, M., Shepson, P. B., Carroll, M. A., Griffith, S., Dusanter, S., and Stevens, P. S.: Nitric acid photolysis on forest canopy surface as a tropospheric nitrous acid source, Nature Geosci., 4, 440-443, doi:10.1038/NGEO1164, 2011. 